\title{
Critical Thinking Ability With Guided Inquiry Model on Science Learning
}

\author{
Santoso* and Tomi Hidayat
}

\author{
Muhammadiyah University of Bengkulu \\ ${ }^{*}$ Corresponding author. Email: santosonursandy@umb.ac.id
}

\begin{abstract}
This study aims to determine how guided inquiry models could improve students' critical thinking ability. This study is such a kind of qualitative content analysis. The study was done by analyzing articles from different journals. Each journal was nationally accredited. The author of each article focused on extending the Guided Inquiry Model's implementation could increase students' critical thinking ability. Qualitative data analysis was conducted. The results of those articles showed that there was an increase in critical thinking skills by implementing guided inquiry models on science learning, and there are factors that influence the success of the inquiry model on the essential skills of thinking of students, including mental readiness, student effectiveness, and teaching skills in facilitating learning which greatly determines the success of the guided inquiry
\end{abstract}

Keywords: Critical thinking, Guided inquiry, Science learning.

\section{INTRODUCTION}

Education is one aspect that determines the future of the nation. In this connection, the government continues to strive to improve education quality. Improving the quality of the teachers and the staff, revising the curriculum, and updating the facilities have been done by the government to improve education quality.

Education can be defined as a way to create an environment of learning activities to have students who have the potential to become religious, have selfcontrol, multiple intelligence, and nationality [1].

Senior High School is as the initial implementer in the world of education. Early education is a serious concern in its implementation. However, the educational process carried out to achieve educational goals must begin with learning processes carried out by teachers, especially at the high school level. The teacher must pay attention to good learning components, namely, mastery of materials, strategies, methods, and skills in varied teaching so that student learning outcomes will be better.

Teaching and learning science at high school are to make the students confident in all of Gods' creatures.
Secondly, to develop the knowledge about concepts of science especially applied in daily life. Third, to enhance students' attitude toward the development of science. Fourth, to develop the skills to explore and solve problems. Fifth, to become aware of preserving the environment. Sixth, to become responsible for preserving nature as one of God's creatures, and seventh, to gain basic concepts of science

In the science learning process, planting good and correct concepts is necessary. This is because science is a continuous science from the basic level to a higher level. The mastery of the science concept at the basic level determines the science concept's mastery at the next level. Therefore, the implementation of science learning must be emphasized by students. It is students who are active while the teacher is only a motivator and facilitator. Also, based on the 2006 KTSP curriculum, science learning in Senior High School is required to make students have high PAIKEM [2]. The science curriculum is perfected to improve the quality of education nationally.

Thus, based on the previous explanation, the research was conducted, which investigates three research articles that focused on exploring the 
phenomena of increasing critical thinking ability by implementing the Guided Inquiry Model.

\section{RESEARCH METHODS}

This study used qualitative content analysis as the study method to explore the phenomena of the implementation of the Guided Inquiry Model and its effect on students' learning performance from three different studies published in the national accredited journals.

The qualitative method is a research method used by qualitative researchers to explore the phenomena of a certain context or explore the content of the object study to determine the facts, describe the phenomena being investigated, and make conclusions $[3,4,5]$.

The data were collected from three different research articles that describe how the Guided Inquiry Model influences students' learning outcomes. The data then were analyzed using thematic analyses.

\section{RESULTS AND DISCUSSION}

Based on the analysis, the facts showed in the research studies that Guided Inquiry Model was proved to be effective in improving students' learning performance. The stages in the Inquiry Model are thought to be able to train students to develop critical thinking skills, namely the aspect of interpretation. Students can classify problems or phenomena so that they could describe the phenomena clearly. An active discussion can improve critical thinking skills, such as problem identification, classification, categorization, and interpretation [6]. The way to analyze something can be gained by identifying problems so that concepts and descriptions can be obtained as well as submitting opinions through learning experiences [7]. The students trained evaluation skills through discussion activities. Students could assess each other or respond to their friends' statements, provide alternative answers, and evaluate information sources during the discussion. By accepting input from the presentation results, this stage allows students to develop critical thinking skills in the evaluation aspect $[8,9]$.

Moreover, the ability of the students to make inferences or conclusions increased by implementing the Inquiry Model. This is because students' critical thinking skills can be increased by involving students in making statements, solving problems, and drawing conclusions. Further, students' self-regulation after being treated using the Inquiry Model has also increased

One researcher explained that the ability to think scientifically would develop through inquiry-driven by curiosity. Curiosity is a thinking activity that must be stimulated and practiced regularly [10]. This is in line with what other researcher stated that the Inquiry Model is a series of learning activities that maximally involves all students' abilities to search and investigate critically, logically and analytically.

The application of the guided inquiry learning model is applying learning, which has a strong relationship with students who have a high curiosity to learn to find something through a continuous learning process [11]. In guided inquiry learning, students are trained to learn to find something, both pre-existing and new things that students find in learning under the teacher's guidance as a good facilitator, wise, and liked.

Guided inquiry learning is an approach where this approach will appear in every learning model activity. This means that students learn to find something earlier through continuous stages or processes. Students' memory of learning will last a long time and challenge students to continue learning to find new things and solve other learning problems.

Guided inquiry learning has some steps to be implemented. The first step is asking questions. In this step, the teacher asks questions that stimulate students to dare to answer and argue. After that, the teacher guides the students to observe the media or props displayed to write down and communicate their observations properly [12].

The second step of the guided inquiry learning model is that students formulate hypotheses. In this activity, students are formed into small heterogeneous groups consisting of 4 to 6 people. This is in line with the research that showed that students learn together in small groups consisting of 4-6 students who are equal but heterogeneous, ability, gender, ethnicity/race, and each other in cooperative classes. others help each other (1).

Then the third stage of the guided inquiry learning model, namely collecting data, that is, students collect data on all activities carried out by each member in the group, then the data is grouped. Furthermore, the data is sorted based on the number of observations about environmental preservation and the use of old resources. The fourth stage of the guided inquiry learning model is data analysis. In this activity, the teacher provides students the opportunity to present their work to the class using media/props that the teacher has prepared. Other groups pay attention, provide responses or objections to whether the presenter group's work is by other groups. If not, why, in this case, the group others can estimate the appropriate answer.

The guided inquiry learning model's application to increase science learning activities and outcomes are student-centered learning through teacher guidance [13]. In this case, students act as learning subjects, and the teacher acts as a facilitator who provides guidance. This is emphasized by the expert, who said that guided inquiry is suitable for learning about the concepts and principles fundamental in certain science fields [14]. 
The teacher guides students by asking questions to make it easier for students to find their concepts learned, and the teacher guides students more when working in groups. [15].

The other study about the implementation of Guided inquiry learning was carried out in SMAN 1 Narmada [16]. The research aims to determine the effect of the guided inquiry model on learning outcomes and critical thinking skills of class $\mathrm{X}$ students on biodiversity and the classification of living things. The results showed that the Guided inquiry learning model has a significant positive effect on the students' learning outcomes and critical thinking skills.

Based on the facts on the implementation of learning obtained from observations, one of the researchers concluded that other factors influence the inquiry model's success on students' critical thinking skills, including mental readiness, student effectiveness, and teaching skills to facilitate learning greatly determines guided inquiry [17]

\section{CONCLUSION}

Based on the results of research and discussion, it is concluded: that 1) The guided inquiry model is more effective in improving critical thinking skills than the cooperative learning model, and 2) The guided inquiry model is more effective at improving generic science skills than the cooperative learning model.

\section{ACKNOWLEDGMENT}

The researchers would like to express their gratitude to the team for guidance and advice for all help. They also thanked the Directorate General of Higher Education, who has funded this preliminary study.

\section{REFERENCES}

[1] Undang-Undang Nomor 20 Tahun2003 tentang Sistem Pendidikan Nasional. Jakarta: Depdiknas.

[2] Depdiknas. Kurikulum Tingkat Satuan Pendidikan. Jakarta: Depdiknas. 2006.

[3] Nazir. Metode Penelitian. Jakarta: Ghalia Indonesia. 1988.

[4] Sugiyono. Metode Penelitian Kuantitatif Kualitatif dan R\&D. Bandung: Alfabeta. 2005.

[5] Whitney. The Elements of Resort. Asian Eds. Osaka: Overseas Book Co. 1960.

[6] Jacobsen, David A, dkk. Methods for Teaching. Yogyakarta: Pustaka Pelajar. 2009.
[7] Facione, Peter A. Critical Thinking: What it is and why it Counts. California: The California Academic Press. 2011.

[8] Maseleno, A., Ayshwary, B., Ivanova, T.N., Hashim, W., Nguyen, P.T., Shankar, K., Kristiawan, M., Huda, M. 2019. General Theoretical and Philosophical Aspects of Modern Education. Aspectos Teoricos Filosoficos Generales de la Educacion Moderna. Revista San Gregorio 2019, No. 32 Special Issues August.

[9] Heidare, A., Poor, S.B., \& Poor, F.N., Effect and Evaluation of Creativity Instructional Methods on Creativity of Students. Life Science Journal, 8 (4), 2011, 402-408

[10] Jufri. Belajar dan Pembelajaran SAINS. Bandung: Pustaka Reka Cipta. 2012

[11] Trianto. Model-model pembelajaran Inovatif berorientasi Konstruktivistik. Jakarta: Prestasi Pustaka. 2007.

[12] Winarni, E. Inovasi Dalam Pembelajaran IPA. Bengkulu: Unit Penerbitan FKIP UNIB. 2012.

[13] Winataputra. 1993. Strategi Belajar Mengajar. Jakarta: Universitas Terbuka. 1993

[14] Noviyanti, M \& Yumiati. Model Pembelajaran Inkuiri Terbimbing untuk meningkatkan kemampuan penalaran dan representasi matematis siswa SMP. Skripsi: Unievrsitas Terbuka Jakarta: Tidak Diterbitkan. 2014.

[15] Jauhar, M. Implementasi paikem dari behavioristic sampai konstruktivistik.Jakarta: Prestasi Pustakarya. 2011

[16] Amijaya, S. Lalu, Ramdani, Agus, Merta, Wayan. Pengaruh Model Pembelajaran Inkuiri Terbimbing Terhadap Hasil dan Kemampuan Berpikir Kritis Peserta Didik. .Jurnal Pijar MIPA, 13 (2), 2018. Universitas Mataram. Hal 94-99.

[17] Herman, Nurfathurraohmah, Rubianti, Bakhtiar. 2019. Model Pembelajaran Inkuiri Terbimbing Terhadap Kemampuan BerpikirKritis Peserta Didik MTs Daarul Hikma Kota Bima. Jurnal Biotek, 7(2), 2019. STKIP Bima. Hal 136-147. 